\title{
ANALISIS PENGARUH KINERJA KEUANGAN PERUSAHAAN TERHADAP HARGA SAHAM DAN MANFAATNYA DALAM PENGAMBILAN KEPUTUSAN INVESTASI
}

\author{
Oleh : Aris Susetyo
}

\begin{abstract}
ABSTRAKSI
Tujuan penelitian ini adalah untuk mengetahui pengaruh kinerja keuangan perusahaan yang di-proxy-kan dalam bentuk rasio-rasio keuangan yang terdiri dari return on assets, return on equity, current ratio, inventory turnover, total asset to total liabilitas ratio, dan debt to equity ratio terhadap perubahan harga saham sehingga dapat dijadikan dasar dalam pengambilan keputusan investasi. Sampel yang digunakan dalam penelitian ini seluruh perusahaan manufaktur go publik yang terdaftar di Bursa Efek Jakarta mulai tahun 2000 sampai dengan tahun 2008. Jumlah sampel sebanyak 109 perusahaan dan nama perusahaan diperoleh dari Indonesia Capital Market Directory.

Analisis data dilakukan dengan regresi dan korelasi linier. Hasil analisis menunjukkan tidak terdapat multikolinieritas diantara variabel yang diuji. Analisis varians yang diperoleh diperoleh menunjukkan semua variabel bisa digunakan. Besarnya hubungan antara kinerja keuangan dengan harga saham sebesar $81,4 \%$ dan sisanya merupakan faktor lain yang tidak diteliti.
\end{abstract}

Kata Kunci : kinerja keuangan, harga saham, regresi dan korelasi

\section{PENDAHULUAN}

Investasi di Indonesia baik dalam bentuk penanaman modal dalam negeri maupun penanaman modal asing sejak awal Orde Baru sampai dengan tahun 2000 telah mengalami peningkatan yang signifikan. Peningkatan investasi yang sangat drastis mulai terjadi pada tahun 1990 (Fax Book, 2000). Hal ini sesuai dengan tingkat pertumbuhan ekonomi yang tinggi, sehingga diproyeksikan Indonesia akan menjadi salah satu macan Asia. Pertumbuhan nilai investasi ini mencapai puncaknya pada tahun 1996 dan 1997 (Warsono, 2001:21). Kondisi pertumbuhan yang tinggi tidak dapat bertahan seiring dengan datangnya badai krisis. Krisis ekonomi ini dirasakan oleh
Indonesia jauh lebih berat dibandingkan dengan kawasan lain di Asia. Hal ini disebabkan oleh beberapa faktor yang memperburuk perekonomian di negeri ini. Korupsi, kolusi dan nepotisme (KKN) ternyata tidak terbatas hanya pada sektor negara saja, juga telah mempengaruhi operasional perusahaan (Mahfoedz, 1999:37).

Salah satu komponen penting dalam investasi adalah pasar modal yang mempunyai peran strategis sebagai salah satu sumber pembiayaan dunia usaha. Pasar modal dalam situasi yang berkembang baik, mampu berperan memobilisasi dana bahkan berperan pula dalam mendistribusikan kekayaan melalui mekanisme yang mampu 
melipatgandakan transaksi jual beli saham atau obligasi di pusat maupun daerah (Hamdi, 1999:44).

Harga saham merupakan salah satu indikator keberhasilan pengelolaan perusahaan. Kekuatan pasar ditunjukkan oleh terjadinya transaksi perdagangan saham di pasar modal. Pada prinsipnya semakin baik prestasi perusahaan dalam menghasilkan keuntungan, maka akan meningkatkan permintaan saham perusahaan tersebut, sehingga pada gilirannya akan meningkatkan pula harga saham perusahaan (Kusdiyanto, 1996:39)

Harga saham sebagai indikator nilai perusahaan dipengaruhi oleh berbagai faktor, baik secara langsung atau tidak akan mempengaruhi harga saham perusahaan. Dari sudut pandang pemegang saham faktorfaktor yang berpengaruh terhadap pemegang saham menurut Usman (1990:166) dapat dibagi menjadi tiga kategori yaitu faktor yang bersifat fundamental, faktor yang bersifat teknis serta faktor sosial, ekonomi, dan politik. Faktor tersebut secara bersamasama akan membentuk kekuatan pasar yang berpengaruh terhadap transaksi saham perusahaan, sehingga harga saham akan mengalami berbagai kemungkinan kenaikan harga maupun penurunan harga.

Permintaan investor terhadap saham suatu perusahaan dipengaruhi oleh kinerja perusahaan, yaitu kondisi dan prestasi keuangan perusahaan yang mengeluarkan saham. Kondisi dan prestasi keuangan perusahaan dapat diketahui dengan melakukan analisis terhadap laporan keuangan perusahaan. Hal tersebut disebabkan karena laporan keuangan disusun mengikuti kaidah-kaidah standar penyusunan laporan-laporan keuangan dan diterapkan secara meluas oleh perusahaan-perusahaan. Kaidah dasar akuntansi adalah komparabilitas dan konsistensi. Dengan kaidah tersebut, laporan keuangan yang mereflkesikan kinerja keuangan suatu perusahaan dapat diperbandingkan dengan perusahaan lain atau perusahaan itu sendiri. Pemanfatan rasio keuangan untuk melihat kinerja perusahaan dan untuk memprediksi kinerja perusahaan, secara eksplisit dikemukakn oleh Horrigan (1968) dan Barness (1997). Mengingat pentingnya peranan laporan keuangan sebagai sumber informasi yang biasa di analisis dengan rasiorasio keuangan yang berhubungan dengan harga saham merupakan topik yang sangat menarik maka peneliti tertarik untuk mengadakan penelitian apakah return on assets, return on equity, current ratio, inventory turnover, total asset to total liabilitas ratio, dan debt to equity ratio mempunyai pengaruh terhadap harga saham secara partial;apakah return on assets, return on equity, current ratio, inventory turnover, total asset to total liabilitas ratio, dan debt to equity ratio mempunyai pengaruh terhadap harga saham secara bersama-sama.

\section{LANDASAN TEORI}

\section{Pentingnya Analisis Laporan Keuangan}

Mengadakan interpretasi atau analisis keuangan suatu perusahaan akan sangat bermanfaat bagi penganalisis untuk dapat mengetahui perkembangan finansial perusahaan. Analisis laporan keuangan akan sangat membantu bagi manajer untuk dapat memanfaatkan potensi yang add dalam perusahaannya. Bagi kreditur interpretasi laporan keuangan sangat penting terutama dalam mengambil keputusan untuk memberi atau menolak permintaan kredit dari suatu perusahaan.

Dalam menilai prestasi dan kondisi suatu perusahaan, seorang analisis memerlukan adanya ukuran tertentu. Ukuran yang 
seringkali digunakan dalam analiis keuangan adalah rasio. Rasio adalah alat yang dinyatakan dalam aaritmathical terms yang dapat digunakan untuk menunjukkan hubungan antara dua data keuangan (Riyanto, 1998:329). Analisis dan penafsiran berbagai rasio keuangan akan memberikan pemahaman yang lebih baik terhadap prestasi dan kondisi keuangan daripada analisis hanya terhadap data keuangan saja. Pada umumnya digunakan dua cara untuk menafsirkan rasiorasio keuangan (Husnan, 1992:200-201):

1. analis dapat membandingkan rasio saat ini dengan rasio-rasio di masa lalu dan yang diharapkan di masa yang akan datang untuk perusahaan yang sama;

2. membandingkan rasio-rasio suatu perusahaan dengan perusahaanperusahaan yang lain yang sejenis dan kira-kira sama ukurannya, atau dengan rata-rata industri pada saat yang sama.

\section{Macam-macam Rasio Keuangan}

Apabila dilihat dari sumbernya, dari mana rasio itu dibuat, maka rasio dapat digolongkan menjadi 3 golongan (Riyanto, 1988: 330), yaitu :

1. rasio-rasio neraca (balance sheet ratios) yaitu rasio yang disusun dari data yang berasal dari neraca, misal current ratio, acid test ratio, current ratio, current assets to total assets ratio, current liabilities to total assets ratio;

2. rasio-rasio laba rugi (income statement ratios) yaitu rasio yang disusun dari data yang berasal dari income statement, misal gross profit margin, net operating margin, operating ratio;

3. rasio antar laporan (inter statement ratios) yaitu rasio yang disusun dari data yang berasal dari neraca dan data lainnya yang berasal dari income statement, misal assets turn over, inventory turn over, receivables turnover.

Pada umumnya berbagai rasio yang dihitung bisa dikelompokkan ke dalam empat tipe dasar (Husnan, 1992: 204-217):

1. rasio likuidas, yaitu mengukur kemampuan perusahaan untuk memenuhi kewajiban finansial jangka pendek.

2. rasio leverage, yang mengukur seberapa jauh perusahaan dibelanjai dengan hutang atau dengan kata lain mengukur seberapa banyak dana disupply oleh pemilik perusahaan dalam proporsinya dengan dana yang diperoleh dari kreditur perusahaan.

3. rasio aktivitas, yang mengukur seberapa efektif perusahaan menggunakan sumber dayanya seperti yang digariskan perusahaan. Rasio ini menyangkut perbandingan antara penjualan bersih dengan berbagai investasi dalam aktivaaktiva.

4. rasio provitabilitas, yang mengukur efektivitas manajemen secara keseluruhan sebagaimana ditunjukkan dari keuntungan yang diperoleh dari penjualan investasi yang dimaksudkan untuk mengukur efesiensi penggunaan aktiva perusahaan.

\section{Teori Saham}

Saham merupakan sekuritas yang memberikan penghasilan tidak tetap dari pemiliknya. Pemilik saham akan menerima penghasilan dalam bentuk deviden yang diterima oleh pemegang saham. Besarnya deviden yang diterima oleh para pemegang saham ditentukan oleh penerbit sekuritas yang bersangkutan (Reilly dan Brown, 2000:201). Harga pasar saham dijadkan alat 
pemantau prestasi perusahaan. Harga saham merupakan ukuran indeks prestasi perusahaan, yaitu seberapa jauh manajemen telah berhasil mengelola perusahaan atas nama pemegang saham.

\section{Pendekatan Nilai Saham}

1. Pendekatan Nilai Intrinsik

Nilai intrinsik saham adalah nilai yang didasarkan pada aktiva, produksi, pemasaran, pendapatan deviden, prospek perusahaan dan faktor manajemen. Nilai intrinsik diartikan sebagai cara penentuan nilai saham berdasarkan kemampuan suatu perusahaan . Nilai intrinsik juga disebut sebagai present value atau economic value estimates (Francis, 1984:429). Ada dua pendekatan dalam menilai harga saham di pasar modal (Jogiyanto, 1988:69) yaitu :

a.1. the fundamental approach yakni mempelajari economic analysis, industrial analysis dan company analysis. Atau dengan kata lain dalam mengestimasi harga saham perlu mempertimbangkan pengaruh keadaan ekonomi, kondisi industri, dan kinerja perusahaan yang memasarkan sahamnya melalui pasar modal. Analisis fundamental menggunakan data fundamental, yaitu data yang berasal dari data keuangan perusahaan.

a.2. the technical approach yakni pendekatan yang lebih menekankan pada perilaku harga saham, volume perdagangan saham, serta capital gain. Menurut pendekatan ini pada dasarnya investor adalah bersifat irrasional, dan bursa efek merupakan cermin tingkah laku masyarakat investor.

\section{Pendekatan Nilai Sekarang Saham}

Pendekatan ini disebut dengan metode kapitalisasi laba (capitalization of income method) karena melibatkan kapitalisasi nilai-nilai masa depan yang didiskontokan menjadi nilai sekarang. Jika investor percaya bahwa nilai perusahaan tergantung dari prospek perusahaan tersebut dimasa yang akan datang dan prospek ini merupakan kemampuan perusahaan untuk menghasilkan aliran kas di masa depan maka nilai perusahaan tersebut dapat ditentukan dengan mendiskontokan arus kas di masa depan menjadi nilai sekarang

\section{Tinjauan Penelitian Terdahulu}

Informasi tentang posisi keuangan perusahaan, kinerja perusahaan, aliran kas perusahaan dan informasi lain yang berkaitan dengan laporan keuangan diperoleh dari laporan keuangan perusahaan. Untuk memahami informasi tentang laporan keuangan, analisis laporan keuangan sangat dibutuhkan (Gibson dan Boyer 1980; Gibson 1982; Lev dan Thiagarajan 1993). Analisa laporan keuangan meliputi perhitungan dan interpretasi rasio keuangan. Pemanfaatan rasio keuangan untuk melihat kinerja perusahaan dan untuk memprediksi kinerja perusahaan secara eksplisit dikemukakan oleh Barnes (1987) sebagai berikut :

It is axiomatic from the research reviewed that it is assumed that they are (financial ratios) good indicators of a firm's financial and business performance and characteristics and that they may be used to forecast future performance and characteristics. It is also axiomatic that there 
have been considerable advances in this work; in their stastical nature and their statistical us and in this respect we are much nearer the 'theory of financial ratio's to which Horrigan (1968) reffered p. 457

Lere (1991) mengemukakan pentingnya analisis laporan keuangan dalam bentuk rasio keuangan sebagai berikut :

The financial ratios used by different decision makers differ just as do the decision they make. Numerous studies discuss the usefulness of various financial ratios used as branchmarks against which compare performance. From the external user's point of fiew, financial ratio are used in deciding wheter to purchase a company's stock, to lend cash, or to predict a firm's future financial strength.

Manfaat laporan keuangan dalam mempengaruhi keputusan investor telah diuji oleh beberapa peneliti. Ball dan Brown (1968) menguji kandungan informasi pelaporan laba pada harga saham. Ball dan Brown menemukan bahwa pelaporan laba mempunyai pengaruh yang signifikan terhadap harga saham. Kesimpulan penelitian Ball dan Brown diperkuat oleh beberapa peneliti lain seperti Cornell dan Landsman (1989); Ali (1994).

Penelitian yang menguji rasio keuangan yang lebih komprehensif telah dilakukan oleh Ou dan Penman (1989). Ou dan Penman menguji manfaat analisis laporan keuangan dalam memprediksi keuntungan saham dan menggunakan 68 rasio keuangan. Penelitian Ou dan Penman bertujuan untuk menaksir nilai perusahaan dengan menggunakan laporan keuangan. Ou dan Penman menemukan bahwa rasio keuangan mengandung informasi fundamental yang tidak tercermin dalam harga saham. Untuk membuktikan lebih lanjut kesimpulan penelitian tersebut, $\mathrm{Ou}$ dan Penman melakukan penelitian secara terpisah $\mathrm{Ou}$ (1990) dan Penman (1992).

O'Conner (1973) melakukan pengujian terhadap 10 rasio keuangan dan memprediksi keuntungan saham. O'Conner mendeteksi apakah laporan keuangan dapat membantu para investor untuk menentukan pemilihan investasi saham di pasar modal dengan melihat informasi dalam bentuk rasio keuangan. O' Conner melakukan pengujian terhadap 10 rasio keuangan dan memprediksi keuntungan saham. Analisis dilakukan dengan menggunakan univariate dan multivariate analysis. Penelitaian ini menemukan bahwa rasio keuangan yang bermanfaat berupa total liabilities to net worth, income for common stock to net worth, cash flows to number of commont stocks, current liabilities to inventory, and earning per share to stock price. Study ini dilanjutkan oleh Berlev dan Livnat (1990) yang menambahkan rasio-rasio keuangan selain dari neraca, laba rugi seperti yang digunakan O'Conner dengan rasio keuangan yang dianalisis dari fund flow statement. Kedua peneliti ini menemukan bahwa rasiorasio keuangan yang ditambahkan dari aliran dana ternyata memberikan tambahan informasi ketika digunakan untuk memprediksi retur saham.

Altman (1968) menguji manfaat rasio keuangan untuk menguji kebangkrutan. Altman menggunakan sampel sebanyak 66 perusahaan yang terdiri dari 33 perusahaan bangkrut dan 33 perusahaan tidak bangkrut. Altman menggunakan multivariate discriminant analysis dalam menguji manfaat lima rasio keuangan dalam memprediksi kebangkrutan. Altman menemukan model yang disebut $\mathrm{Zi}$ score, yaitu score dari kombinasi rasio-rasio keuangan untuk memprediksi kesulitan keuangan perusahaan. Rasio yang masuk dalam model 
meliputi working capital to total assets, retained earning to total assets, earning before interest and taxes to total assets, market value of preffered and common stock to book value of liabilities, and sales to total assets. Dari model yang dikembangkan ditemukan bahwa perusahaan yang gagal mempunyai total $\mathrm{Zi}$ score sebesar - 0,258 atau kurang, dan total $\mathrm{Z}$ score perusahaan sehat adalah 4,885. Altman menemukan bahwa rasio keuangan yang terdiri dari profitability, likuidity, dan solvency bermanfaat dalam memprediksi kebangkrutan dengan tingkat kebangkrutan 95\% setahun sebelum perusahaan bangkrut. Tingkat keakuratan tersebut turun menjadi $72 \%$ untuk periode 2 tahun sebelum bangkrut, $48 \%$ untuk periode 3 tahun sebelum bangkrut, $29 \%$ untuk periode 4 tahun sebelum bangkrut, dan $36 \%$ untuk periode 5 tahun sebelum bangkrut. Perluasan study dalam prediksi kebangkrutan dilakukan oleh Dombolera dan Khoury (1980) yang memperluas studi yang dilakukan sebelumnya dengan meneliti 46 perusahaan yang terdiri 23 perusahaan bangkrut dan 23 perusahaan tidak bangkrut dari sektor eceran dan pabrikan. Dombolera dan Khoury menganalisis 19 rasio keuangan dengan menggunakan discrininant prosedure, yang meliputi profitability, activity, likuidity dan indebtedness menunjukkan bahwa rasio keuangan yang digunakan oleh peneliti terdahulu ternyata konsisten memberikan informasi tentang kekuatan prediksi kebangkrutan perusahaan. Untuk perusahaan yang bangkrut ternyata standard deviation, standard error of estimate, dan varience dari net income to sales, net income to net worth dan time interest earned, tidak stabil selama pengamatan. Hasil penelitian Dombolera dan Khoury menunjukkan bahwa rasio keuangan mempunyai kemampuan untuk memprediksi kebangkrutan untuk lima tahun sebelum perusahaan mengalami kebangkrutan. Studi ini dilanjutkan oleh Zmijewski (1983) menambah validitas rasio keuangan sebagai alat deteksi kegagalan keuangan perusahaan. Rasio keuangan dipilih dari rasio-rasio keuangan penelitian terdahulu dan diambil saampel sebanyak 75 perusahaan bangkrut dan 3573 perusahaan sehat dari tahun 1972 sampai 1978. Rasio yang digunakan dikelompokkan dalam rate of return, likuidity, leverage, turn over, fixed, payment coverage, trends, firm size, dan stock return volatility. Dengan menggunakan F-test menunjukkan adanya perbedaan yang signifikan antara perusahaan yang sehat dan yang tidak sehat.

Di Indonesia penelitian tentang manfaat rasio keuangan sudah banyak dilakukan untuk menunjukkan manfaat analisis dari laporan keuangan. Mahfoedz (1994) melakukan penelitian tentang manfaat rasio keuangan dalam memprediksi laba perusahaan dimasa yang akan datang. Dengan mengambil sampel 89 perusahaan go publik yang terdaftar di Bursa Efek Jakarta dari tahun 1989 sampai tahun 1993, Mahfoedz menganalisis 47 rasio keuangan yang dikatagorikan dalam katagori short term-liquidity, long term solvency, profitability, productivity, indebtebness, investment intensiveness, leverage, return on investment dan equity.

Hasil strepwise regression menunjukkan bahwa terdapat13 rasio keuangan yang signifikan dalam prediksi pertumbuhan laba. Rasio keuangan yang signifikan tersebut terdiri dari 1 rasio katagori short term-liquidity, 1 rasio katagori long term solvency, 3 rasio katagori profitability, 1 rasio katagori productivity, 1 rasio katagori indebtebness, 2 rasio katagori leverage, 1 rasio katagori return on 
investment, 2 rasio katagori equity. Deteksi kinerja perusahaan melalui telaah rasio keuangan yang dilakukan oleh Mahfoedz (1999) merupakan deteksi tentang pengaruh krisis moneter yang dialami sejak Juli 1997 ternyata berdampak pada kinerja keuangan perusahaan di sektor tertentu, tetapi tidak pada sektor lain. Dengan membandingkan dua laporan keuangan tahun 1996 dan 1997 yang diterbitkan oleh 129 perusahaan yang terdiri empat sektor satu 32 perusahaan, sektor dua 30 perusahaan, sektor tiga 34 perusahaan dan sektor empat 31 perusahaan. Pembagian sektor ditentukan berdasarkan pengelompokkan dalam Fax Book. Penelitian dilakukan dengan menguji rata-rata rasio keuangan perusahaan pada setiap sektor dengan menggunakan uji-t. Ditemukan bahwa sektor empat terdiri dari property and real estatet, building construction, telecommunication, transportation, durable goods and computer, merupakan kelompok yang paling besar penurunan kinerjanya dibandingkan dengan kelompok sektor lain.

Berbeda dengan Mahfoedz, Halim dan Hidayat (1999) menambahkan faktor ukuran perusahaan dalam menganalisis dampak krisis terhadap kinerja perusahaan, serta menggunakan Manova sebagai alat analisis. Ukuran perusahaan dimasukkan ke dalam analisis, karena intuitif terhadap perbedaan rasio keuangan antara perusahaan kecil, menengah dan perusahaan besar. Zulhawati (2001) menganalisis dampak krisis dengan membandingkan periode sebelum krisis (1996) dan periode krisis (1997), menganalis dampak krisis dengan membandingkan periode krisis 1997 dan 1998. Dengan mengambil sampel pada 207 perusahaan publik yang terdaftar di Bursa Efek Jakarta selain Bank, lemabaga kredit non bank, perusahaan sekuritas, dan perusahaan dengan data outlier. Alat analisis dan variabel penelitian yang digunakan Manova dan memasukkan ukuran perusahaan dalam analisis. Dari penelitian ini diperoleh kesimpulan bahwa perusahaan publik yang berukuran kecil ternyata mempunyai daya tahan yang cukup tinggi dalam menghadapi krisis moneter dibandingkan kelompok perusahaan menengah/sedang maupun besar. Ini ditunjukkan dengan penurunan kerja fianacial baik current ratio, debt to equity maupun return on investment yaang lebih kecil setelah masa krisis dibandingkan dengan penurunan kinerja financial kelompok perusahaan menengah/sedang maupun besar. Hamdi (1999) dalam studinya menemukan bahwa rasio keuangan yang terdiri dari assets turn over, current ratio, operating margin ratio, net profit margin ratio, return on assets, return on equity, dan debt to equity ratio secara bersama-sama maupun partial bermanfaat dalam pengambilan keputusan investasi, artinya dapat digunakan investor dalam mengambil keputusan investasi dalam membeli saham. Dengan melakukan survei pada 197 perusahaan konsumsi go publik yang terdaftar di Bursa Efek Jakarta dari tahun 1990 sampai 1996.

Berbagai literatur terdahulu seperti yang diringkas di atas menunjukkan bahwa rasio keuangan yang diektraksi dari laporan keuangan merupakan indikator yang bermanfaat dalam rangka membantu pengguna dalam membuat keputusan bisnis. Ratio keuangan dapat digunakan sebagai explanatory variabel dalam menilai kinerja keuangan perusahaan, nampak dalam berbagai studi terdahulu bahwa rasio keuangan mampu menjelaskan kinerja perusahaan dengan baik. Dalam hubungannya dengan studi ini, riset terdahulu memberikan gambaran bahwa rasio keuangan tertentu yang diektraksi dari 
laporan keuangan yang dipublikasikan perusahaan dapat digunakan dalam membuat keputusan bisnis.

\section{Hipotesis Penelitian}

Dalam penelitian ini dikemukakan 2 hipotesis

$\mathrm{H}_{1}$ : variabel return on assets, return on equity, current ratio, inventory turnover, total asset to total liabilitas ratio, dan debt to equity ratio mempunyai pengaruh terhadap harga saham secara pastial;

$\mathrm{H}_{2}$ : variabel return on assets, return on equity, current ratio, inventory turnover, total asset to total liabilitas ratio, dan debt to equity ratio mempunyai pengaruh terhadap harga saham secara bersama-sama;

\section{METODOLOGI PENELITIAN}

\section{Populasi dan Sampel}

Populasi yang digunakan sebagai sample frame penelitian ini adalah seluruh perusahaan manufaktur yang terdaftar (listed) di Bursa Efek Jakarta. Seluruh perusahaan tersebut merupakan objek yang akan dipilih secara random untuk mewakili populasi. Jumlah populasi perusahaan yang go publik tersebut meliputi seluruh perusahaan manufaktur yang listing di Bursa Efek Jakarta. Nama-nama perusahaan tersebut diperoleh dari Indonesia for Economic and Financial Research.

Sampel perusahaan yang digunakan dalam penelitian meliputi seluruh perusahaan manufaktur yang go publik di Bursa Efek Jakarta. Kualifikasi untuk dipilih menjadi sampel adalah :

1. perusahaan menerbitkan laporan keuangan selama sepuluh tahun berturutturut, yaitu mulai tahun 2000 sampai dengan kwartal kedua 2008;
2. laporan keuangan harus mempunyai tahun buku yang berakhir 31 Desember. Hal ini untuk menghindari adanya pengaruh waktu parsial dalam penghitungan rasio keuangan.

Jumlah perusahaan manufaktur yang go publik yang menjadi sampel dari penelitian ini sampai tahun 2008 adalah 109 perusahaan. Data perusahaan di atas berdasarkan pada Fax Book tahun 2008.

\section{Metode Pengumpulan Data}

Metode yang digunakan dalam pengumpulan data adalah data sekunder dari Indonesian Capital Market Directory, JSX Monthly Statistic, JSX Quarter Statistics dan Fax Book.

\section{Pengukuran Variabel}

Variabel Independen (variabel bebas)

Variabel Independen adalah kinerja perusahaan yang terdiri dari rasio-rasio keuangan. Variabel Indepenen terdiri dari enam rasio keuangan yang direpleksikan dari penelitian Altman (1968), Beaver (1966 dan 1968), Libby (1968), Zmejewski (1984), dan Mahfoedz (1998). Rasio keuangan tersebut yaitu :

a. rasio profitabilitas yaitu indikator kemampuan perusahaan dalam memanfaatkan ekuitas para pemilik atau pemegang saham untuk menghasilkan laba sesudah pajak. Profitabilitas dalam penelitian ini diproxykan dengan variabel perbandingan antara laba sesudah pajak dan total aktiva (ROA), perbandingan antara laba sesudah pajak dan equitas (ROE);

b. rasio likuiditas yaitu indikator kemampuan perusahaan menyelesaikan kewajiban jangka pendeknya. Likuiditas dalam penelitian ini diproxykan dengan variabel perbandingan antara aktiva 
lancar dan utang (CR), perbandingan antara harga pokok penjualan dengan rata-rata persediaan (IT)

a. rasio solvency yaitu indikator kemampuan perusahaan dalam menyelesaikan utang jangka panjang. Solvency dalam penelitian ini diproxykan dengan variabel perbandingan antara total aktiva dan total hutang (TA/TL), dan perbandingan antara total utang dan equitas (DER).

\section{Variabel Dependen (variabel tidak bebas)}

Variabel dependen adalah harga saham. Data harga saham yang digunakan adalah hargasaham tahunan. Harga saham yang digunakan dalam penelitian ini yaitu harga pada akhir periode (closing price)

\section{Instrumen Penelitian}

Penelitian ini dilakukan dengan membandingkan kinerja perusahaan yang dinyatakan dalam rasio-rasio keuangan dengan harga saham dan melakukan pengujian statistik untuk mengetahui kinerja perusahaan mempunyai pengaruh yang signifikan terhadap harga saham

\section{Metode Analisis Data}

Untuk melakukan pengujian hipotesis dalam penelitian ini dilakukan tes statistik dengan menggunakan uji regresi dan korelasi. Dalam penyusunan persamaan regresi berganda berdasarkan data-data yang diperoleh untuk menggambarkan dan menjelaskan hubungan antara komponenkomponen berupa rasio keuangan dengan harga saham di pasar sekunder.

\section{HASIL PENELITIAN \\ Deskripsi Statistik}

Deskripsi variabel yang digunakan dalam penelitian ini tercantum dalam tabel 3 berikut ini

Tabel 1

Deskripsi Variabel Sampel

\begin{tabular}{|c|c|}
\hline $\begin{array}{c}\text { Nama } \\
\text { Variabel }\end{array}$ & Keterangan \\
\hline $\mathrm{X}_{1}$ & Return on Assets (ROA) \\
$\mathrm{X}_{2}$ & Return on Equity (ROE) \\
$\mathrm{X}_{3}$ & Current Ratio (CR) \\
$\mathrm{X}_{4}$ & Inventory Turnover (IT) \\
$\mathrm{X}_{5}$ & Total Assets to Total Liabilities \\
$\mathrm{X}_{6}$ & (TA/TL) \\
$\mathrm{Y}$ & Debt to Equity Ratio (DER) \\
& Harga Saham \\
\hline
\end{tabular}

Deskripsi data yang dipergunakan dalam analisis ini adalah tercantum pada lampiran 4, secara ringkas dapat dilihat dalam tabel berikut:

Tabel 2

Deskripsi Variabel Sampel

\begin{tabular}{|c|c|c|c|c|c|}
\hline Variabel & $\mathrm{N}$ & $\begin{array}{c}\text { Nilai } \\
\text { Minimum }\end{array}$ & $\begin{array}{c}\text { Nilai } \\
\text { Maksimum }\end{array}$ & Mean & $\begin{array}{c}\text { Standar } \\
\text { Deviasi }\end{array}$ \\
\hline Harga Saham & 109 & 269,75 & 52,700 & 3155,50 & 6882,19 \\
ROA & 109 & $-0,14025$ & 0,520125 & 0,0437 & 0,1069122 \\
ROE & 109 & $-927,273$ & 49,8975 & $-27,64986$ & 112,9022156 \\
CR & 109 & 0,2925 & 8,2775 & 1,7391514 & 1,3855018 \\
IT & 109 & 0,17 & 284,0175 & 7,45844633 & 27,5713079 \\
TA/TL & 109 & 1,192 & 12,795 & 2,2806030 & 1,7347765 \\
DER & 109 & 0,0825 & 45,765 & 4,5375229 & 7,8070782 \\
\hline
\end{tabular}

Sumber : data diolah 
Jumlah sampel yang dipergunakan adalah 109 perusahaan manufaktur yang terdaftar di Bursa Efek Jakarta. Total perusahaan yang terdaftar 183 perusahaan, tetapi 74 perusahaan dikeluarkan dari analisis. Apabila salah satu variabel mempunyai nilai yang jauh di atas rata-rata sampel (outlier) harus dikeluarkan. (Heir, et al. 1992).

Nilai saham yang paling rendah adalah sebesar 268,75 dan yang paling tinggi 52.700. Nilai ROA minimum sebesar 0,14025 sedangkan nilai maksimum sebesar 0,520125, sedangkan nilai ROE minimum sebesar $\quad-927,273$ dan nilai masksimum sebesar 49,8975. Nilai CR minimum 0,2925 dan nilai maksimum 8,2775 , sedangkan nilai TA/TL yang minimum sebesar 1,192 dan nilai maksimumnya sebesar 12,279. sedangkan nilai DER minimum 0,0825 dan nilai maksimumnya sebesar 45,765 .

\section{Analisis Regresi}

Analisis regresi dipergunakan untuk melihat hubungan antara pengaruh kinerja keuangan yang diproxykan oleh rasio keuangan dengan harga saham (lampiran 3). Data hasil regresi adalah sebagaimana dalam dibawah ini :

Tabel 3 Analisis

Regresi

\begin{tabular}{|c|c|c|c|}
\hline $\begin{array}{c}\text { Variab } \\
\text { el }\end{array}$ & $\begin{array}{c}\text { Coefficie } \\
\text { nts }\end{array}$ & $\mathrm{t}$ & Sig \\
\hline $\begin{array}{c}\text { Consta } \\
\mathrm{nt}\end{array}$ & $\begin{array}{c}31389,49 \\
4\end{array}$ & $\begin{array}{c}3,55 \\
7\end{array}$ & $\begin{array}{c}0,00 \\
0\end{array}$ \\
\hline ROA & $\begin{array}{c}21240,81 \\
0\end{array}$ & $\begin{array}{c}3,50 \\
3\end{array}$ & 0,00 \\
& 0 & 0 \\
\hline ROE & $\begin{array}{c}31270,10 \\
\end{array}$ & 3,55 & 0,00 \\
& 3 & 3 & 0 \\
\hline CR & $\begin{array}{c}21826,04 \\
6\end{array}$ & $\begin{array}{c}3,90 \\
1\end{array}$ & 0,00 \\
& 6 & \multicolumn{2}{|c}{} \\
\hline
\end{tabular}

\begin{tabular}{|c|c|c|c|}
\hline IT & 22931,52 & 3,40 & 0,00 \\
& 5 & 9 & 0 \\
\hline TA/TL & 22389,72 & 3,31 & 0,00 \\
& 9 & 2 & 0 \\
\hline DER & 21174,34 & 3,39 & 0,00 \\
& 5 & 9 & 0 \\
\hline
\end{tabular}

Sumber : Data diolah

Dari harga di atas dapat disusun persamaan regresi sebagai berikut :

$$
\begin{aligned}
\mathrm{Y}= & 31389,494+21240,810 \mathrm{X}_{1}+ \\
& 31270,103 \mathrm{X}_{2}+21826,046 \mathrm{X}_{3} \\
& +22931,525 \mathrm{X}_{4}
\end{aligned}
$$

$(3,553)$

$$
(3,901)
$$

$$
+22389,729 \mathrm{X}_{5}+21174,345
$$

$\mathrm{X}_{6}$

$$
(3,312)
$$

Hasil regresi menunjukkan bahwa variabel ROA, ROE, CR, TA/TL, DER mempunyai nilai positif, artinya variabel $R O A, R O E, C R$, $I T, T A / T L$ dan $D E R$ memiliki hubungan yang positif terhadap harga saham.

\section{Pembuktian Hipotesis I}

Untuk menguji pengaruh variabel independen secara individual terhadap variabel dependen dalam persamaan linier berganda data dapat dilihat dalam lampiran 4 . Proses pengujian pada hipotesa pertama, sebagai berikut :

Dengan tingkat kepercayaan $5 \% t_{\text {tabel }}=$ 3,143, maka :

1. Harga $t_{\text {hitung }}$ variabel $X_{1}=3,503>$ dari $\mathrm{t}_{\text {tabel }} 0,05=3,143$. Jadi $\mathrm{H}_{0}$ ditolak dan menerima $\mathrm{H}_{1}$, menunjukkan bahwa variabel bebas $\mathrm{X}_{1}$ secara statistik menjelaskan variabel tergantung $\mathrm{Y}$. 
2. Harga $t_{\text {hitung }}$ variabel $X_{2}=3,533>$ dari $\mathrm{t}_{\text {tabel }} 0,05=3,143$. Jadi $\mathrm{H}_{0}$ ditolak dan menerima $\mathrm{H}_{1}$, menunjukkan bahwa variabel bebas $\mathrm{X}_{2}$ secara statistik menjelaskan variabel tergantung $\mathrm{Y}$.

3. Harga $t_{\text {hitung variabel }} \mathrm{X}_{3}=3,901>$ dari $t_{\text {tabel }} 0,05=3,143$. Jadi $\mathrm{H}_{0}$ ditolak dan menerima $\mathrm{H}_{1}$, menunjukkan bahwa variabel bebas $\mathrm{X}_{3}$ secara statistik menjelaskan variabel tergantung $\mathrm{Y}$.

4. Harga $t_{\text {hitung variabel }} \mathrm{X}_{4}=3,409>$ dari $t_{\text {tabel }} 0,05=3,143$. Jadi $\mathrm{H}_{0}$ ditolak dan menerima $\mathrm{H}_{1}$, menunjukkan bahwa variabel bebas $X_{1}$ secara statistik menjelaskan variabel tergantung $\mathrm{Y}$.

5. Harga $t_{\text {hitung }}$ variabel $\mathrm{X}_{5}=3,312>$ dari $t_{\text {tabel }} 0,05=3,143$. Jadi $\mathrm{H}_{0}$ ditolak dan menerima $\mathrm{H}_{1}$, menunjukkan bahwa variabel bebas $\mathrm{X}_{1}$ secara statistik menjelaskan variabel tergantung $\mathrm{Y}$.

6. Harga $t_{\text {hitung variabel }} \mathrm{X}_{6}=3,339>$ dari $\mathrm{t}_{\text {tabel }} 0,05=3,143$. Jadi $\mathrm{H}_{0}$ ditolak dan menerima $\mathrm{H}_{1}$, menunjukkan bahwa variabel bebas $\mathrm{X}_{1}$ secara statistik menjelaskan variabel tergantung $\mathrm{Y}$.

Tabel 4

Analisa Varians ROA, ROE, CR, IT, TA/TL dan DER

\begin{tabular}{|c|c|c|c|c|c|}
\hline $\begin{array}{c}\text { Sumber } \\
\text { Variasi }\end{array}$ & $\begin{array}{c}\text { Jumlah } \\
\text { Kuadrat }\end{array}$ & df & Kuadrat Tengah & $\mathrm{F}_{\text {hitung }}$ & $\begin{array}{c}\text { Probabilitas } \\
\text { Kesalahan }\end{array}$ \\
\hline Regresi & $5,84 \mathrm{E}+08$ & 6 & 97291127,741 & 3,190 & 0,000 \\
Sisa & $4,53 \mathrm{E}+09$ & 102 & 44427699,996 & & \\
Total & $5,12 \mathrm{E}+09$ & 108 & & & \\
\hline
\end{tabular}

Sumber : Data diolah

Dari hasil perhitungan dalam tabel 4, menunjukkan bahwa $\mathrm{F}_{\text {hitung }}$ sebesar 3,190 dengan tingkat kesalahan 0,000. Nilai $F_{\text {tabel }}$ dengan tingkat kepercayaan $5 \%$ dan derajat kebebasan $\left(\mathrm{df}_{1}\right)=6\left(\mathrm{df}_{2}\right)=102$, nilai $\mathrm{F}_{\text {tabel }}$ sebesar 2,180 , oleh karena $F_{\text {hitung }}(3,190)>F_{\text {tabel }}$
Kesimpulan yang dapat dikemukakan bahwa variabel $X_{1}, X_{2}, X_{3}, X_{4}, X_{5}, X_{6}$, secara signifikan dapat menjelaskan variabel bergantung Y. Dengan demikian dapat disimpulkan bahwa secara individual atau parsial mempunyai pengaruh signifikan secara statistik antara kinerja perusahaan yang dinyatakan dalam rasio keuangan terhadap harga saham. Dengan demikian hipotesa pertama dapat di terima.

\section{Pembuktian Hipotesis II}

Dalam pembuktian hipotesa kedua, digunakan analisis ui $\mathrm{F}$ Statistik (multiple regression) yang dapat digunakan untuk melakukan pengujian dalam memprediksi kontribusi variabel-variabel independen terhadap variabel dependent. Kriteria pengujiannya adalah apabila $F_{\text {hitung }}>F_{\text {tabel, }}$ maka $\mathrm{H}_{0}$ ditolak, dan sebaliknya apabila $\mathrm{F}_{\text {hitung }}<\mathrm{F}_{\text {tabel, }}$ maka $\mathrm{H}_{0}$ diterima. Perhitungan analisis varians enam variabel bebas dapat dilihat dalam tabel berikut ini 
secara bersama-sama mempunyai pengaruh terhadap harga saham. Dengan demikian hipotesa kedua terpenuhi.

Pengujian Asumsi Klasik Model Regresi Linier

Pengujian asumsi klasik dimaksudkan untuk memeriksa adanya pelanggaran terhadap asumsi klasik model regresi linier. Pelanggaran terhadap asumsi klasik model linier akan menyebabkan koefisien-koefisien regresi memiliki standar error yang besar, sehingga mengalami keandalan penaksiran. Selain itu, pelanggaran terhadap asumsi klasik juga menyebabkan statistik yang dihasilkan dari analisis varians tidak akurat.

\section{Pengujian Asumsi Multikolinieritas.}

Pengujian Asumsi Multikolinieritas dilakukan untuk melihat ada tidaknya hubunga linier antar variabel bebas. Pengujian ini dilakukan dengan menggunakan varians inflation factor (VIF). Gambaran mengenai VIF setiap variabel bebas dalam penelitian ini dapat dilihat pada tabel berikut ini

Tabel 5

Analisis Nialai VIF Variabel ROA, ROE, CR, IT, TA/TL dan DER

Untuk Menguji Asumsi Hubungan Antar Variabel Bebas
Sumber : Data diolah

Pada tabel 5 tampak bahwa model regresi antara perubahan harga saham dengan

\begin{tabular}{|c|c|c|}
\hline No & $\begin{array}{c}\text { Variabel } \\
\text { Bebas }\end{array}$ & VIF \\
\hline 1 & ROA & 1,222 \\
2 & ROE & 1,110 \\
3 & CR & 1,125 \\
4 & IT & 1,104 \\
5 & TA/TL & 1,179 \\
6 & DER & 1,152 \\
\hline
\end{tabular}

semua variabel bebas yang diamati, nilai VIF terbesar adalah 1,222 dari variabel ROA. Pada model regresi ini nilai VIF dari semua variabel yang terkandung dalam model mendekati 1. Dapat disimpulkan bahwa tidak terdapat multikolinieritas yang serius antar variabel ROA, ROE, CR, IT, TA/TL dan DER.

2. Pengujian Asumsi Homoskedastisitas

Pengujian asumsi Homoskedastisitas dilakukan untuk mengetahui kehomogenan varians error dari model regresi. Pengujian ini dilakukan dengan menggunakan Uji Glejser, yaitu dengan meregresikan nilai absolut residuals yang diperoleh yaitu $\left(\mid \mathrm{e}_{\mathrm{i}}\right.$ |) atas variabel ROA, ROE, CR, IT, TA/TL dan DER.

Tabel 6

Nilai t Statistik Untuk Regresi Nilai Absolut Residual Terhadap Variabel ROA, ROE, CR, IT, TA/TL dan DER.

\begin{tabular}{|c|c|c|c|c|}
\hline No & Variabel Bebas & $\mathrm{t}_{\text {hitung }}$ & $\mathrm{t}_{\text {tabel }}$ & Kesimpulan \\
\hline 1 & ROA & 3,503 & 3,707 & Tidak Signifikan \\
\hline
\end{tabular}




\begin{tabular}{|c|c|l|l|l|}
\hline 2 & ROE & 3,553 & 3,707 & Tidak Signifikan \\
3 & CR & 3,901 & 3,707 & Tidak Signifikan \\
4 & IT & 3,409 & 3,707 & Tidak Signifikan \\
5 & TA/TL & 3,321 & 3,707 & Tidak Signifikan \\
6 & DER & 3,399 & 3,707 & Tidak Signifikan \\
\hline
\end{tabular}

Sumber : Data diolah

Pada tabel 6 tampak semua nilai $t_{\text {hitung }}$ untuk koefisien-koefisien regresi nilai mutlaknya berkisar antara 3,321 sampai 3,503. Dengan demikian tidak ada koefisien regresi yang signifikan. Dari hasil analisis varians, diperoleh $F_{\text {hitung }}$ sebesar 3,190. Dengan taraf kepercayaan $5 \%$ diperoleh nilai $F_{\text {tabel }}$ sebesar 3,707, dengan demikian $\mathrm{F}_{\text {hitung }}<\mathrm{F}_{\text {tabel. }}$ Kesimpulan yang diperoleh bahwa model regresi nilai mutlak residual terhadap variabel bebas secara keseluruhan tidak signifikan.

3. Pengujian Asumsi Korelasi Serial

Untuk menguji ada atau tidaknya masalah kasus autokorelasi dalam kasus persamaan regresi linier berganda, dapat dideteksi dengan menggunakan metode Durbin Watson. Dalam tabel D.W pada $\alpha 5 \%$ adalah D.W $\mathrm{W}_{\mathrm{U}}=1,746, \mathrm{D} \cdot \mathrm{W} \cdot \mathrm{L}=1,720$ dan (4D. $\left.W_{U}\right)=2,254$. Dengan D.W yang diperoleh dari hasil estimasi model regresi sebesar 2,001 dapat disimpulkan bahwa tidak terdapat korelasi serial baik positif maupun negatif diantara distrurbance term regresi yang ditaksir karena D.W lebih kecil dari (4D. $\mathrm{W}_{\mathrm{U}}$.

\section{KESIMPULAN}

Kesimpulan yang dapat ditarik dari penelitian ini adalah sebagai berikut :

1. Secara parsial kinerja keuangan perusahaan yang dinyatakan dalam rasio-rasio keuangan yang terdiri dari variabel rate of return on assets, rate of return on equity, current ratio, inventory turn over, total assets to total liabilities, debt to equity ratio yang mempunyai pengaruh terhadap harga saham, setelah dilakukan pengujian semua variabel significant Hal ini menunjukkan investor sangat menaruh perhatiannya pada pemanfaatan semaksimal mungkin sumber-sumber ekonomi yang tersedia untuk mendapatkan laba yang semaksimal mungkin.

2. Secara bersama-sama kinerja keuangan perusahaan yang dinyatakan dalam rasio keuangan berpengaruh terhadap harga saham. Hasil pengujian statistik dengan menggunakan uji $\mathrm{F}$, nilai $\mathrm{F}_{\text {hitung }}=3,190$ $>F_{\text {tabel }} 2,180$ dan memiliki probabilitas kesalahan dari taraf signifikan sebesar 0,005 sehingga $\mathrm{H}_{0}$ ditolak dan menerima $\mathrm{H}_{1}$. Besarnya hubungan antara kinerja keuangan perusahaan dengan harga saham sebesar 81,4 \% dan sisanya merupakan faktor lain yang tidak diteliti. 


\section{DAFTAR PUSTAKA}

Altman, E.I. (1968), Financial Ratios, Descriminant Analysis and Predictor of Coorporate Bankruptcy", The Journal of Finance, September p. 589-609

Arief, Sritua (1993), Metodologi Penelitian Ekonomi, Jakarta: UI Press

Ball, R., and P. Brown (1968), "An Empirical Evaluation of Accounting Income Numbers", Journal of Accounting Research, p. 159-178

Barnes, Paul (1987), "The Analysis and Use of Financial Ratio" : A Riview Article, Journal of Business Finance Accounting, Winter p. 449-459.

Beaver, W.H (1996), "Financial Ratios as Predictor of Failure", Journal of Accounting, p. 71111

Dayan, Anto (1986) Pengantar Metode Statistik, Jilid II, Jakarta: LP3ES

Dombolera, Ismael G., and Sarkis Khoury, J. (1980), "Ratio Stability and Coorporate Failure”, Journal of Finance, September p. 1017-1026

Greene, W.H (1993) Econometric Analysis, 2nd ed, NY:MacMillan Publishing Co

Gijarati, Damodar (1995), Basic Econometrics, Singapura: McGraww-Hill

Jogiyanto (1998), Teori portofolio dan Analisis Investasi, Edisi Pertama, Yogyakarta: BPFE

Kusdiyanto (1996), “Analisis Beberapa Faktor Yang Mempengaruhi Harga Saham BankBank Go Publik di Indonesia", Empirikka, Nomor 17, hal: 39-49

Lere, John C (1991) Managerial Accounting: A Planning, Operating and Control Framework, NY: John Willey and Son Inc

Mahfoedz, Mas'ud (1999), 'Profit Kinerja Finansial Perusahaan-Perusahaan Yang Go Publik di Pasar Modal ASEAN', Jurnal Ekonomi dan Bisnis Indonesia, Volume 14, Nomor 3, hal 56-57

O’Corner, Melvin C (1973), 'On the Usefulness of Finansial Ratios to Investor in Common Stock', The Accounting Rivew, April, p. 339-352

Riyanto, Bambang (1998), Dasar-Dasar Pembelajaran Perusahaan, Edisi 4, Yogyakarta: BPFE

Reilly, Frank., and Brown, Keith C (2000), Investmen Analysis and Portofolio Managenet, Sixth Edition, The Dryden Press

Usman, Marzuki (1990), ABC Pasar Modal Indonesia, Jakarta: ISEI

Warsono (2000), "Dampak Krisis Moneter Terhadap Bursa Efek Indonesia", Usahawan, Nomor 4 Tahun XXVII April, hal 13-18

Zmijewski (1993), "Methodological Issues Related to the Estimation of Financial Distress Model", Journal of Accounting Research, p. 59-82

Zulhawati (2001), "Analisis Dampak Krisis Moneter Dan Ukuran Perusahaan Terhadap Kinerja Keuangan Publik di Bursa Efek Jakarta (Studi Kasus Pada 207 Perusahaan Publik di BEJ)" Kompak, Nomor 2 Mei, hal 209-229. 